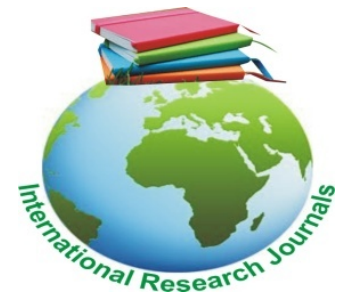

Educational Research (ISSN: 2141-5161) Vol. 7(1) pp. 010 -015, February, 2016

Available online@ http://www.interesjournals.org/ER

DOI: http:/dx.doi.org/10.14303/er.2016.009

Copyright (C) 2016 International Research Journals

Full Length Research Paper

\title{
Availability and use of selected visual materials in the teaching of English writing skills in primary schools in Kericho County, Kenya
}

\author{
${ }^{1}$ Charles Kimutai Kurgatt, ${ }^{2}$ Macdonald Omuse Omuna \\ ${ }^{1}$ Kericho Boys Boarding: P.O. Box 804- 20200, Kericho, Kenya \\ ${ }^{2}$ St.Stephens'Keng'atuny High School: P O Box 21-50422, Amagoro, Kenya \\ Corresponding Author's E-mail:kckurgatt@gmail.com, omusem433@gmail.com
}

\begin{abstract}
Competence in writing remains a challenge to learners of English as a second language particularly at primary school level. This calls for early intervention in teaching through use of visual materials that enhance high levels of retention and easy retrieval of information. The purpose of this paper, therefore, was to establish the extent to which visual materials are available for use in the teaching of writing skills in Kenyan public primary schools. The objective of the study was to assess the availability and use of visual materials in schools that enhance the development of pupils' writing skills in upper primary schools. The Research design used was descriptive survey design. 21 public schools were selected through purposive and multistage sampling. A total of 42 teachers and 84 class 7 pupils participated in the study. Information was collected using questionnaires, structured interviews and observations.Findings reveal that printed materials were the main resources available in the classrooms in most schools with $\mathbf{3 6}$ out of $\mathbf{4 2}$ teachers indicating that they were available and adequate. This study suggests that the government should increase Free Primary Education allocation to allow schools purchase a variety of learning resources other than textbooks
\end{abstract}

Keywords: Availability, writing skills, visual materials

\section{INTRODUCTION}

Writing a coherent and effective text, according to Kellogg (2008) is a difficult and protracted achievement of cognitive development. This contrasts sharply with the acquisition of speech. Spoken language is normally highly developed by the age of 5 with a high working vocabulary when ability to comprehend and produce grammatical sentences is attained. However, writing an extended text at an advanced level involves the language system as well as engaging our cognitive systems for memory and thought. An analysis of pupil performance in English composition at the Kenya Certificate of Primary Education (KCPE) examination remains a challenge to learners (KCPE Newsletters, 2014).

From the foregoing, it is indicative that the approach to the teaching of writing skills to young learners has not been exhaustive and calls for change of strategy on how to reduce the extraneous cognitive load during learning experiences and to captivate the learner's interest in writing skills development. Towards this objective, the role of availability and utilization of selected visual materials in primary schools was explored to enhance teaching and learning of English writing. It was anticipated that it would assist the learner better understand and retain information when ideas, words and concepts are associated with images as postulated by the poet Simonides and Aristotle, as cited in Benson (1997) thus: "Words are the images of things. Without image, thinking is impossible." (p141).

Through this perspective, therefore, there was need to investigate on the availability of visual learning strategies such as storyboards, mind maps and visual brainstorming and out of this, the development of young learners' writing skills in enabling pupils to think, reason, argue and express themselves effectively in English. 


\section{Study Objective}

The objective of this paper was to assess the availability and use of selected visual materials in enhancing the teaching of English writing skills.

\section{Research Question}

The following question grounded the study:

Which visual materials available in schools enhance the development of pupils' writing skills?

\section{Related Literature}

Language is a crucial instrument to humanity as it facilitates flow of information which in turn leads to world economy, knowledge and exchange of information. Language is useful to its users when one is able to communicate the desired information in a logical and coherent manner. This is extremely critical in the written form since the writer has no opportunity to clarify or explain facts to an inquisitive reader. Children and young adults develop by having real experiences with writing, reading, speaking, listening, and thinking while also supported by more experienced literacy learners (Coates, 2004; Coker, 2014).

English has been adopted as the official language in Kenya due to its place as one of the most influential languages in the world. According to Pegg (2012) English language is used globally as a tool for trade, in conferences and exchange of information. Kenyan students, therefore, find it easy to interact with most of the other members of the human race due to the ability to communicate in this global language. Batolva (2006) observes that English is taught in schools mostly as a second language since learners come into contact with it as they begin formal education at the age of around five years. Focus is mainly on improving students' speaking, listening and reading skills and in the process of doing this, the curriculum has ignored the development of the students' writing skills.

An analysis of pupil performance in English composition writing in the national examination of the class eight Kenya Certificate of Primary Education show that low quality composition writing remains a challenge to pupils (KCPE Newsletters, 2014). From the foregoing, it is indicative that the approach to the teaching of writing skills has not been exhaustive and calls for review of strategy in order to improve the development of writing skills.

\section{Availability of Visual Materials}

The teaching and learning of English writing skills largely depends on the availability of visual materials (Grossman and Thompson, 2008). According to Evans (2012) various visual resources enhance writing skills. These include story boarding, mind maps and graphic posters. She avers that visual resources help students to understand and interpret information. These techniques can provide structure for writing and can help students to focus their thoughts and ideas. On the same note, Fianu (1999) cited in Agbadzi (2009) observes visual materials are implements which a teacher can use to make visual impression on the learners during instruction for effective comprehension of the content.

In justifying the role of visual materials in contributing towards the learning process, Silverman (2006) avers that visual, auditory and tactile help learners' process information. The researchers concur that most learners take in new information through visualization of the whole concept. The benefits of using visual learning techniques are many. For example, visual materials help learners clarify thoughts and information, they reinforce understanding through connection, assist learners to integrate knowledge with prior learning and also help the teacher to identify learners' misconceptions. Visual tools likewise provide direction for thinking (Foliaki, 2012).

Cassady (2014) advances the fact that visual materials are effective in conveying ideas and content more easily than verbal descriptions for visual learners, and are important learning enhancements in the classroom. According to Cassady, course content enriched with charts, diagrams, photographs, visual presentations, videos and maps is more easily absorbed by pupils. However, as a means of facilitating teaching and learning, visual materials are not just a means of transforming knowledge, but the most important thing is the extension of both the teacher and the chalkboard (Newby et al., 2006).

Finally, (Makokha and Wanyonyi, 2015) note that there is insufficiency on the availability of instructional materials and that teachers rely on chalk and talk method to teach language skills. They conclude that learners do not perform well in language skills development due to insufficient resources. It is, therefore, suggestive that student performance is greatly influenced by classroom experiences as indicated by Kennedy (1989) cited in (Onchera and Manyasi, 2013) who note that there is need for more observation of what actually happens in classrooms in order to give some idea on why students get the results as they do.

\section{Use of Visual Materials}

In an effort to reduce workload on the working memory for enhanced efficiency, the use of visual materials has proved effective in the teaching of other subjects as reported in a study that highlighted the importance of visual representations both for teachers and pupils in 
their teaching and learning of mathematics. The use of multiple representations in general is an important part of teachers' knowledge of mathematics and they can play an important role in the explanation of mathematical ideas (Leinhardt, Putnam, Stein, and Baxter, 1991).Brophy (1991) states thus:

Skilled teachers have a repertoire of such representations available for use when needed to elaborate their instruction in response to student comments or questions or to provide alternative explanations for students who were unable to follow the initial instruction"(p.352)

It is therefore instructive from the above quote that imbibing the use of visual materials into the teaching of English writing skills may facilitate student self-learning and thus enhance conceptualization of concepts. Learners are expected to write with an eye for detail, using words that describe something by "seeing" with sound, sight and taste to help them focus on details for story writing (Giles et al., 2003). They further note that visual learning style is effective and useful to the learners where they are expected among others to replace words with symbols or initials, translate concepts into pictures and diagrams. They are also expected to highlight personal notes or textbooks with different colors, practice turning visuals back into words and making flashcards of key information with words, symbols and diagrams.

As revealed in the literature review, visual resources facilitate the teaching and learning of English writing skills. The studies however do not reflect the availability and use of visual resources in the learning of writing skills in primary schools. The researchers hardly came across any study on the availability and use of visual materials in Kericho County, Kenya. It is in view of these gaps that this study was conducted.

\section{Study Design and Methodology}

This study was carried out in public primary schools within Ainamoi Division of Kericho Sub-county in Kericho County. The choice of Ainamoi division for the study was due to its low academic performance especially in English composition writing just like most other sub counties that have contributed to Kericho County being ranked position 36 out 47 in KCPE 2013 results (KNEC Report 2013). The study employed descriptive survey design. This was considered appropriate since it would allow the researchers collect quantifiable information from the sample (Kombo and Tromp 2006 cited in Onchera and Manyasi, 2013). The population from which the sample for this study was drawn consisted of 68 public primary schools, 42 teachers of English language and 84 standard seven pupils. The researcher initially used multistage sampling as described by Cochran (1977) cited in Nafiu, et al (2012) to divide them into subsets thus distinguish them per their administrative zones. A representation in form of a percentage was then used to sample each zone. (Orodho and Kombo, 2002) argue that at least $30 \%$ of the target population can be considered ideal as this would facilitate generalization of the findings.

Using purposive sampling, the researchers selected 4 schools from Municipality zone, 5 schools from Ainamoi zone, 5 schools from Kapsaos zone, and 7 schools from Kapsoit zone. Therefore the research involved 21 out of 68 public primary schools, thus representing $30 \%$ of the study population. From each of the 21 schools, purposive sampling was used in selecting class seven where simple random sampling was used to select 2 teachers teaching English subject as participants in the study, making a total of 42 teachers. Table 1 provides a summary of the sample grid size.

The researchers employed stratified sampling to select 1 school from Municipality zone, and 2 schools each from Ainamoi zone, Kapsaos zone, and Kapsoit zone, making a total of 7 schools used for the conduct of classroom observations in the classes that had been selected from the 21 schools. This was a 10\% representation of the target population as recommended by Mugenda and Mugenda (2003) cited in Macharia (2013). A total of 42 teachers and 84 class 7 pupils participated in the study. Information was collected using questionnaires for teachers, interview schedules for pupils, observation checklist for materials available in the classroom and lesson observation schedule to record use of visual materials. These research instruments were designed by the researchers in line with the research objective and research question.

The teachers' questionnaire consisted of two sections: $A$ and B. Section A captured Biographical information, which was used to obtain teachers' gender, age bracket, highest academic qualification, experience in teaching the subject and training background. Questions in Section B sought to record the availability of instructional technologies in the sampled schools categorized under printed, projected, non-projected and visual materials. The questionnaires were administered for a maximum of 30 minutes per teacher. The pupils' interview schedule was divided into section A and B. Section A recorded the learners' biographic data which entailed their gender and age brackets. Section B contained questions on the availability of visual materials in the classroom that may be used to develop writing skills. The interview lasted for a maximum of 40 minutes per pupil.

The observation checklist and schedule were used to get the kind of visual materials available in the classroom and how they were utilized. The researchers observed one English lesson from each of the sampled seven schools which lasted for a period of 35 minutes each.

To validate the test items, the questionnaire and interview schedule were discussed with educational 
Table 1: Ainamoi Division Sample Grid Size

\begin{tabular}{lcc}
\hline Zone & Public Schools & Sampled Schools (30\%) \\
\hline Municipality & 12 & 4 \\
Ainamoi & 18 & 5 \\
Kapsaos & 16 & 5 \\
Kapsoit & 22 & 7 \\
Total & $\mathbf{6 8}$ & $\mathbf{2 1}$ \\
\hline
\end{tabular}

Source: Researchers (2014)

Table 2: Availability Printed Resources

\begin{tabular}{lccccc}
\hline Resource & $\begin{array}{c}\text { Available and } \\
\text { Adequate (\%) }\end{array}$ & $\begin{array}{c}\text { Available and } \\
\text { Not Adequate }\end{array}$ & Not Available & N/A & Results \\
\hline Textbooks & $36(87.5)$ & $6(14.3)$ & $0(0)$ & - & A and A \\
Journals & $1(2.4)$ & $14(33.3)$ & $24(57.1)$ & $3(7.1)$ & Not Available \\
Magazines & $6(14.3)$ & $12(28.6)$ & $22(52.4)$ & - & Not Available \\
School Pamphlets & $6(14.3)$ & $9(21.4)$ & $24(57.1)$ & $3(7.1)$ & Not Available \\
Wall Maps & $18(42.9)$ & $16(38.1)$ & $7(16.7)$ & $1(2.4)$ & A and A \\
Newspapers & $12(28.6)$ & $10(23.8)$ & $19(45.2)$ & $1(2.4)$ & Not Available \\
\hline
\end{tabular}

Key

N/A - Not applicable (Respondents failed to give options)

$A$ and $A$ - Available and Adequate

Source: Researchers (2014)

research experts for their input and verification. A pilot study was conducted in two schools in order to eliminate items that would have likely elicited irrelevance or no responses. The instrument was then amended accordingly after piloting. A test-retest strategy was to establish the reliability of the instruments. The first and second tests were correlated and a coefficient of reliability of 0.76 was realized thus implying that there was high degree of reliability of research instruments.

\section{Data analysis}

Data analysis was systematically done as per the objectives of the study. Quantitative data collected using questionnaires from the teachers and pupils' interview schedules were processed by coding the closed ended questions for descriptive analysis. In the case of open ended questions, data was categorized, themes established, data coded and entered into the computer for descriptive analysis. After the descriptive analysis, the researchers reported and discussed the findings using tables and charts.

\section{RESULTS AND DISCUSSION}

The study involved 42 teachers out of whom 13(31\%) were male and 29(69\%) were female. 26(62\%) teachers were Primary One (P1) certificate holders. 10(23.8\%) were holders of Diploma in Education certificate while $6(14.2 \%)$ were Bachelor of Education degree holders. This data indicates that majority of teachers who are assigned to teach English as a subject are P1 teachers. This study therefore concludes that teachers' gender, age, teaching experience and acquisition of Diploma and Degree certificates has no influence in determining personnel to teach writing skills in upper primary classes.

The study involved 84 pupils. 44(53.2\%) were boys while $40(46.8 \%)$ were girls. Majority of the pupils (60\%) were aged between 12-14 years. This implies that the pupils who participated in the study had an ideal age to provide reliable data.

\section{Availability of Materials for Teaching English Writing Skills}

The researchers sought to investigate the availability of materials for teaching English writing skills in the classroom. Table 2 presents the results.

These results show that textbooks $36(87.5 \%)$ are the major printed resources available for use in teaching English writing skills in public schools. This was followed by wall maps used by 18 (42.9\%), newspapers 12 $(28.6 \%)$, magazines $6(14.3 \%)$, pamphlets $6(14.3 \%)$ and journals $1(2.4 \%)$. This agrees with data from pupils interviewed for example, Pupil 4 from School 4 said 'we are always issued with English textbooks to use during writing lessons'. Pupil 2 from School 6 said that 'Our 
Table 3: Availability and Use of Visual Materials

\begin{tabular}{lccccc}
\hline Resource & A and A & A and NA & Not Available & N/A & Results \\
\hline Story Boarding & $1(2.4)$ & $4(9.5)$ & $35(83.3)$ & $2(4.8)$ & Not Available \\
Mind Maps & $3(7.1)$ & $3(7.1)$ & $36(85.7)$ & - & Not Available \\
Visual Brainstorming & $3(7.1)$ & $10(23.8)$ & $21(50.0)$ & $8(19.0)$ & Not Available \\
Pictures & $12(28.6)$ & $24(57.1)$ & $3(7.1)$ & $3(7.1)$ & A \& NA \\
Drawings & $10(23.8)$ & $28(66.7)$ & $4(9.5)$ & - & A \& NA \\
Graphics & $1(2.4)$ & $21(50.0)$ & $18(42.9)$ & $1(2.4)$ & A \& NA \\
Diagrams & $17(40.5)$ & $22(52.4)$ & $3(7.1)$ & - & A \& NA \\
\hline
\end{tabular}

Key

$A$ and $A$ : Available and Adequate

$A$ and NA: Available and Not Adequate

N/A: Not applicable (Respondents failed to give options)

Source: Researchers (2014)

teacher always insist that we buy many books to assist us in writing English compositions.' This is also corroborated by the results of the observation checklist which confirmed that textbooks were the most available in $6(85.7 \%)$ out of the 7 lessons observed.

The findings of the study is in line with the findings by Orina (2001) who revealed that print media are commonly used in schools though not being mediated. It is worth noting that Arokwu (2003) who undertook a similar study but on textbooks only, maintained that textbooks are available in schools. These study findings are also in consonance with those of Nwafor (2014) who confirmed the availability of textbooks in schools, low availability of three dimensional objects and that teachers do not improvise materials.

Thereafter, the researchers sought to establish the availability and use of selected visual materials for teaching English writing skills. The results are presented on Table 3.

From Table 3, it is evident that $17(40.5 \%)$ of the respondents said that diagrams were the most available and used visual materials followed by pictures 12 (28.6\%), drawings $10(23.8 \%)$ of the respondents. Nonetheless, more than half of the respondents stated that some materials were available but not adequate. These include drawings 28 (66.7\%), pictures 24 (57.1\%), diagrams 22(52.4\%) and graphics 21(50.0\%). However, mind maps and storyboarding were indicated as not available by majority of the respondents as reported by 36 respondents representing $85.7 \%$ and 35 respondents representing $83.3 \%$ respectively of all the respondents. 8 respondents representing $19.0 \%$ of the total respondents failed to respond on availability and use of visual brainstorming strategy in the classroom. It is illustrative from this report that the selected visual materials namely story boarding, mind maps and visual brainstorming are rarely available and utilized in the classroom. This finding is consistent with Luvisia (2003) who found out that there was insufficiency on the availability of instructional materials in the teaching of language skills and that teachers relied on chalk and talk method to teach.

The study further sought to establish from the teachers how frequently instructional resources were available and used in the classroom. Findings reveal that out of the four categories of instructional resources (printed, projected, non-projected resources and visual materials), printed materials were the most frequently available and used in class with 35 out of the 42 respondents, representing $83 \%$ reported that some were used in every lesson. This was supported by pupils interviewed who reported that the most commonly available printed resources were textbooks as prescribed in the 'Orange book' that guides schools on the approved titles of reference and textbooks to be purchased for use by Kenyan schools. The pupils interviewed indicated that they borrowed learning materials because they were not available. However, results indicate that learners used all means to access and utilize materials though not available. One pupil, respondent 2 blatantly said, "We borrow from other pupils who have some of them,' while respondent 4 said that, "We get them from our friends in class." This underscores use though availability is a challenge.

Observations revealed that there were very few materials available and used during the actual teaching in the classroom and more so during the lesson development stage. It was observed that there was no resource materials used at both the introductory and lesson development stages. However, it was observed that at least a resource was used at the conclusion stages in all the 7 lessons observed to give assignments to pupils.

The low usage of visual materials could suggest that most lessons are dominated by 'teacher-talk' yet they are meant to enhance creative writing skills' development. Findings of many researchers like Nijstad et al. (2003), Essley (2005), Stephens and Hermus (2007), Abraham (2008) and Qattami (2010) all advance that there are 
many benefits that accrue from the use of these visual materials to teaching and learning.

\section{CONCLUSION}

The results of this paper show that at primary school level, printed resources such as textbooks and wall maps are available and adequate in most schools. These resources were majorly provided by the schools and subsidized by parents. Non-projected resources like charts, globes, cartoons and models were inadequate though teachers could not utilize the few available ones effectively and frequently. Visual materials that include pictures, drawings and diagrams were greatly disregarded in terms of use during lesson development. However, other resources such as newspapers, pamphlets, magazines and journals were available in very few schools and yet not adequate. This study also revealed that diagrams, drawings and pictures were the most available and used resources in the teaching of English writing skills in primary schools. However, mind maps, graphics, visual brainstorming and story boarding strategies were hardly utilized by the teachers.

\section{RECOMMENDATIONS}

Based on the findings and conclusions thereof, it is recommended that besides textbooks and wall maps, teachers should also use newspapers, pamphlets, magazines and journals in the teaching of English writing skills. In addition, the use of visual brainstorming, mind maps and story boarding can be employed to enhance the development of pupils' writing skills. This would captivate learner interests and thus eliminate the monotony of using textbooks only.

\section{REFERENCES}

Abraham S (2008). Storyboarding: Comics, graphic novels, and engaging learners. Multimedia and Internet @Schools, 15 (3), 2527.

Arokwu T (2003). Availability and utilization of instructional materials (textbooks) in teaching biology in selected secondary schools in Agwu local government of Enugu state. Unpublished dissertationsubmitted to Science and Computer Education Enugu State University of Science andTechnology.

Agbadzi EK (2009). Design and construction of selected instructional materials for visual arts in Ghanaian colleges of Education. Master's Thesis. Accra, Ghana: Accra Institute of Technology.

Batolva J (2006). Spotlight on limited English proficient students in the United States. Migration Policy Institute. OELA Newsline. U.S. Department of Education. Available online at: http://www.ncela.gwu. edu/newsline/archives/2006/02/

Benson PJ (1997). Problems in picturing text: A study of visual/verbal problem solving. Technical Communication Quarterly, 6(2), 141160. Retrieved Dec. 26, 2013, from EBSCOhost database (Professional Development Collection).

Brophy J (1991). Conclusion. Advances in research on teaching Vol. 2, pp. 349-364. In J. Brophy (Ed.) Greenwich, CT: JAI Press.
Coates J (2004). Women, Men and Language: A sociolinguistic account of gender differences in language (3rd ed.). England: Harlow Press.

Coker W (2014). Language and Communication in Structural Society. Michigan Technological University, Houghton, MI, USA. Retrieved on $6^{\text {th }}$ June, 2014 from http://www. language-and-society.org /journal/3-1/language_discourse_society.

Cassady $L$ (2014). Visual materials enhance learning. Retrieved from: http://www.ehow.com/info_8246564_visual-materials-enhance learning. $\mathrm{Html}$

Essley R (2005). The odd fish story. Voices from the Middle, 12 (4), 15-20.

Foliaki V (2012). Learning resources: Visual-aids in the classroom. Retrieved from http://repository.usp.ac.fj/5521/1/EDG14_Criteria for_Visuals_\%28V._Foliaki\%29.pdf on $12^{\text {th }}$ June, 2014.

Evans C (2012). Visual tools for the classroom. Retrieved from http://www.ehow.com/info_7996432_visual-tools-classroom.html \#ixzz2zJUEdIX2 on $19^{\text {th }}$ April, 2014

Giles E, Pitre S, Womack S (2003). Multiple intelligences and learning styles. In M. Orey (Ed.), Emerging perspective on learning, teaching, and technology. Retrieved on $21^{\text {st }}$ April, 2014 from http://projects.coe.uga.edu/epltt/

Kellogg RT (2008). Training writing skills. A cognitive developmental perspective. J. of writing research, 1 (1), 1-26.

Kenya National Examination Council (2013). KCPE Newsletter. Nairobi: KNEC.

Kenya National Examination Council (2014). KCPE Newsletter. Nairobi: KNEC.

Luvisia JC (2003). A Study of Availability and Use of Instructional Resources in Teaching Kiswahili Grammar in Selected Secondary Schools of Bungoma District, Kenya. Unpublished Med Thesis, Moi University. Kenya.

Grossman P, Thompson C (2008). Learning from curriculum materials: Scaffolds for new teachers? Teaching and Teacher Edu, 24(8), 2014-2026.

Leinhardt G, Putnam RT, Stein MK, Baxter J (1991). Where subject knowledge matters. Advances in Research on Teaching, 2, 87-113.

Macharia EW (2013). The effects of global financial crisis on the financial performance of commercial banks offering mortgage finance in Kenya. Intl. J. of Soc.Sci. and Entrepreneurship, 1 (2), 688-701.

Makokha RN, Wanyonyi KM (2015). The Utilization of Instructional Resources in Teaching Kiswahili Poetry in Secondary Schools in Kenya. Intl J. of Academic Res. in Business and Soc. Sci, 5(8), 10-18.

Nwafor CE, Eze SO (2014). Availability and utilization of instructional materials in the teaching of basic science in selected secondary schools in Abakaliki Education Zone of Ebonyi State, Nigeria. Global j. of bio-science and biotechnology. G.J.B.B. 3 (3), 292-295.

Onchera PO, Manyasi BN (2013). Functional writing skills for effective communication: the English language classroom in Kenya, Kenya. JETERAPS J, 4 (6), 842-846.

Nafiu LA, Oshungade LO, Adawara AA (2013). Generalization of multistage cluster sampling using finite population. Intl J. of Engineering and Applied Sci. April. 3 (1), 31-44.

Nijstad BA, Stroebe W, Lodewijkx HFM (2003). Production blocking and idea generation: Does blocking interfere with cognitive processes? J. of Experimental Social Psychology, 3 (9), 531-548.

Orina WM (2001). Availability, utilization and management of geography teaching- learning resources in Kenyan secondary schools. A case of Nyamira County. Unpublished M.Ed. Thesis, Kenyatta University. Nairobi, Kenya.

Orodho A, Kombo D (2002). Research methods. Nairobi: Kenyatta University, Institute of Open Learning.

Pegg D (2012). The 25 most influential languages in the World. Free world press. Available at: http://list25.com/the-25-most-influentiallanguages-in-the-world/5/

Qattami N (2010). Methods of teaching gifted and talented. Amman: Dar Al-maseera.

Silverman F (2006). Learning styles: District administration. New York: Macmillan Publishers.

Stephens P, Hermus C (2007). Making art connections with graphic organizers. School Arts: The Art Education Magazine for Teachers, 106 (8), 55. 